\title{
A SURVEY ON ECTOPARASITES OF SOME FRESHWATER FISH AT QENA GOVERNORATE, UPPER EGYPT
}

\author{
Mahmoud A. El-Seify ${ }^{\text {, *; }}$ Ismail S. Elshahawy ${ }^{2}$; \\ Asmaa M. Metwally'; Marwa M. Fwaz ${ }^{2}$ \\ ${ }^{1}$ Department of Parasitology, Faculty of Veterinary Medicine, \\ Kafrelsheikh University, Kafrelsheikh, Egypt \\ ${ }^{2}$ Department of Parasitology, Faculty of Veterinary Medicine, \\ South Valley University, Egypt. \\ * E. mail address: melseify2012@yahoo.com
}

\begin{abstract}
Three species of fish (Oreochromis niloticus, Clarias lazera and Lates niloticus) were collected from Qena, Upper Egypt during the period from April, 2012 to the end of March, 2013. Upon their inspection, of 6 of ectoparasites species were recovered 3 monogeneans (Cichlidogyrus arthracanthus, Euryhaliotrema lovejoyi and Dactylogyrus spp.), two crustaceans (Lamproglena monody and Ergasilus sarsi) and one protozoan (Henneguya assuiti). The overall prevalence of infection was $12.03 \%$ and the highest peak was observed in O. niloticus with $19.4 \%$ (14/72) and the lowest percent was recorded in L. niloticus with $5.6 \%$ (4/72). Also, seasonal dynamics among the examined fish were recorded. The study revealed the occurrence of one monogenean trematode; Euryhaliotrema lovejoyi for the first time in Upper Egypt.
\end{abstract}

Keywords: Freshwater fish, Ectoparasites, Egypt, Prevalence 


\section{INTRODUCTION}

Healthy fish are important to man as a good source of protein in man's diet and as a vector of some human disease pathogens..

However, fish like any other animal could be infected by several kinds of pathogens including parasitic once, about $80 \%$ of fish diseases are parasitic especially in warm water fish (Eissa, 2002).

All species of fish are vulnerable to various parasitic infections depending on the species of fish and the type of stream inhabited.

Fish parasites and diseases constitute one of the most important problems confronting the fishery biologist today Ravichandran et al. (2007). Pathological conditions resulting from parasites and diseases assume high magnitude of epidemics under crowded and other unnatural conditions (Ravichandran et al., 2010).

Parasitic infections, especially ectoparasites from monogenetic flukes and protozoa are the most dangerous groups affecting skin and gills that induces slimness of the skin, irritation, destruction of gills, anorexia, excessive mucus production (Reed et al. 2003) and impaired breathing (Lom, 1995). The synergistic action of the parasites may cause mortalities (Osman, 2001).

Parasitic crustaceans are invariably ectoparasitic on fish and have a direct life cycle, often with a considerable period of time spent off the host. Parasitic stages are usually blood feeders on gills, skin or fins of the host and in large numbers can have serious pathogenic effects (Lester and Hayward, 2006).

$\overline{\text { Kafrelsheikh Vet. Med. J. Vol. } 11 \text { No. } 2 \text { (2013) }}$ 
A Survey On Ectoparasites Of Some Freshwater Fish At Qena ...

Therefore, this study aimed to investigate the ectoparasitic fauna of some freshwater fish species that were collected from the Nile River at Qena Governorate and to elucidate a spotlight on their infection status. This study will also add to the current knowledge on parasitic infections of cultured fish in Egypt.

\section{MATERIAL AND METHODS}

A total number of 216 randomly selected fish samples representing 3 fish species (72 Oreochromis niloticus (Boulti), 72 Clarias lazera (Carmoot) and 72 Lates niloticus (Kishr-bayad) were collected either alive from fishermen or fresh as possible from fish markets at Qena Governorate, Upper Egypt, and submitted for parasitological investigation at the laboratory of Parasitology; Faculty of Veterinary Medicine; South Valley University in ice box after packed in plastic bags, labeled with different data about the investigated fish specimens as fish species, date and the site of collection during the period extended from the beginning of April, 2012 to the end of March, 2013.

Fish specimens were killed by vertebral separation. Length and weight were recorded, and the inner surface of the gill cover and the branchial cavity were firstly examined by naked eyes and hand lens for the presence of any gross lesions or cysts. Then, the gill cover was removed with scissors exposing the gill arches and lamellae which then examined for detection of any protozoal cyst or parasitic crustacean, later on each gill arch was put in Petri-dish with few amount of saline with the help of a blunt needle, gill lamellae with separated to facilitate the detection of attached Monogeneans parasites by microscopical examination.

$\overline{\text { Kafrelsheikh Vet. Med. J. Vol. } 11 \text { No. } 2 \text { (2013) }}$ 
Furthermore, Smears were taken from body surface, fins and gills, then spread on dry clean slide, and air dried. Any detected protozoal cysts were dissected out and compressed gently between slide and cover slide. The smears were fixed in methyl alcohol for about 5 minutes, and then stained by $10 \%$ Giemsa stain for 30-45 minutes. Then, washed under running water, air dried and examined under microscope using oil immersion lens (Luck, 1977).the recovered parasites were identified using keys of Bonham and Guberlet (1937), Yamaguti (1963) and Gussev (1985).

\section{RESULTS}

\section{I- Parasite survey results:}

During the present research 3 species of fish were examined, all of which were found to be infected at least by one parasite species. Among 216 fish studied, 26 (12.03\% of total sample) were found to be infected. Additionally, the highest infection rate was observed in $O$. niloticus with $19.4 \%(14 / 72)$ and the lowest percentage was recorded in L. niloticus with $5.6 \%$ (4/72), the infection rate in other species; C. lazera was $11.1 \%$ $(8 / 72)$ as illustrated in Table (1) graphs $(1,2,3)$.

The same table displayed that among the infected fishes, in total $6.5 \%$ were found to be infected with monogenetic trematodes, $3.7 \%$ with crustacea and $1.9 \%$ with protozoa.

The obtained results showed that the overall infection rate of monogenetic trematodes among O. niloticus; C. lazera and L. niloticus 
A Survey On Ectoparasites Of Some Freshwater Fish At Qena ...

was $13.9 \%, 5.6 \%$ and $0 \%$ respectively, while for crustacea, both $O$. niloticus and L. niloticus had the same percent of infection (5.6\%) without any record of infection in C. lazera during the period of study.

In respect to protozoan infection, the present research recorded that the overall prevalence in C. lazera was $5.6 \%$, while both $O$. niloticus and L. niloticus were free from infection.

In respect to the seasonal dynamics of monogenetic trematodes, the peak infection rate among $O$. niloticus was recorded during winter season $(27.8 \%)$, with a gradual decline in autumn season $(16.7 \%)$, then by spring $(11.1 \%)$ and finally no infection was recorded in summer season appeared free from infection. But in C. lazera the highest percentage was noticed during spring season (11.1\%), then decline in summer and autumn seasons (5.6\%), and finally there was no infection was detected in winter season.

The present investigation revealed the occurrence of six parasites including three monogenetic trematodes namely, Cichlidogyrus arthracanthus, Euryhaliotrema lovejoyi and Dactylogyrus spp., two from crustacea Lamproglena monody and Ergasilus sarsi, and one from protozoa Henneguya assuiti.

Most of fish investigated in this study, showed a variety of parasitic infections, except L. niloticus which was infected only with Ergasilus sarsi.

$\overline{\overline{\text { Kafrelsheikh Vet. Med. J. Vol. } 11 \text { No. } 2 \text { (2013) }}}$ 
Among monogenetic trematodes, the most prevalent and abundant species were Cichlidogyrus arthracanthus (8.3\%), Euryhaliotrema lovejoyi, (5.6\%), while Dactylogyrus sp. represented the lowest infection rate $(4.2 \%)$ as displayed in Table (2) graph (4).

In respect to crustacea, only two parasites namely, Lamproglena monody (5.6\%) and Ergasilus sarsi (4.2\%) were found in skin of $O$. niloticus and L. niloticus respectively, while the only detected protozoan species Henneguya assuiti was found in gills of $C$. lazera with a total percentage of $4.2 \%$. as displayed in Table (3) and Graph (5). Moreover, the same table displayed that the mean intensity of infection of Lamproglena monody, Ergasilus sarsi and Henneguya assuiti cyst was 2, 4 and 4 respectively.

In respect to seasonal fluctuation of ectoparasitic crustacea and protozoa, the highest infection rate of Lamproglena monody among $O$. niloticus was observed in winter $(16.7 \%)$ and the lowest rate was noticed in autumn (5.6\%), while in the other seasons; summer and spring there were no infection. But in L. niloticus the highest peak was noticed in winter as well $(11.1 \%)$ and the lowest was reported in both spring and autumn (5.6\%); without any infection appeared in summer season. Furthermore, the present work showed that the peak prevalence of Henneguya assuiti was observed during winter season (16.7\%).

\section{II- Morphological results:}

Tables (4 and 5) summarized the most common feature of the recovered ectoparasites in this investigation. 


\section{DISCUSSION}

Fish are hosts to a variety of parasitic organisms which can influence population dynamics (Minchella and Scott 1991, Roche et al 2010), decrease host fitness and alter host behavior or morphology which increases predation risks.

\section{I- Monogenetic trematodes:}

The obtained results showed that the total prevalence of monogenetic trematodes among examined $O$. niloticus in Qena Governorate was $13.9 \%$. This result was nearly in accordance with those mentioned previously by Adawy (2000) who recorded the prevalence was $10.42 \%$ in Dakahlia Governorate. On contrary, the present results was lower as compared to that mentioned by El-Nobi (1998); Eman (2008) and El-Seify et al. (2011) who found that the infection rate was, $20.5 \%$ in Abbassa area, 32.9\% in Kalubia Governorate and 33.3\% in Kafrelsheikh Governorate respectively. These variations might be attributed to the inhibitive quality of physical (Depth, current, temperature) and chemical (Oxygen, salinities) factors of the environment and fish species.

Regarding to their seasonal prevalence among examined $O$. niloticus in Qena Governorate, the present investigation displayed that the highest peak was recorded during winter season, where the infection rate was $27.8 \%$, followed by autumn season $(16.7 \%)$, then by spring $(11.1 \%)$ and finally no infection was detected in summer season. These results were not in accordance with that stated by Saleh and El-Nobi (2003) who mentioned that the highest percentage of monogenea 
infection in $O$. niloticus was recorded during summer season (48.8\%), followed by spring (37.5\%) and autumn (35.15\%), while the lowest percentage was reported during winter season (26.8\%). Additionally, the present data was not in line with the results obtained previously $b$ Mohamed (2009) who revealed that the highest seasonal dynamics of monogenea in $O$. niloticus in Sharkia Governorate and Abbassa fish farms was observed during autumn (66.66\%), followed by winter (56.81\%), summer (31.91\%) and spring (20.21\%). These variations among different authors could be attributed to the difference in the microhabitat distribution of monogenean parasites which depend on parasite species, its developmental stage, on host fish species and on the immune response of the host. In addition to a biotic factors of the water environment specially the water temperature which directly affects the reproduction and survival of parasites and determines the immune response of the host (Blazek et al., 2008).

In total examined $C$. lazera, our study revealed (5.6\%) prevalence of monogenetic trematodes which is considered lower than that formerly obtained by Ramadan (2000) 36.28\%; Abd El-Maged (2009) in Dakahlia Governorate (51.7\%), Endrawes (2001) (45.8\%), El-Bouhy et al. (2006) (14.8\%) in Sharkia, Damietta and Fayium Governorates and Abo-Esa (2008) (25\%) in Giza governorate. This variation might be attributed to changes in water quality in different localities.

The highest seasonal prevalence of monogenea in C. lazera was in spring (11.1\%), followed by summer and autumn (5.6), but not detected in winter season. This result was agreed with that reported by Endrawes (2001) who recorded that the highest infection rate was observed during Kafrelsheikh Vet. Med. J. Vol. 11 No. 2 (2013) 
A Survey On Ectoparasites Of Some Freshwater Fish At Qena ...

spring season. On contrary, this result was not in consistent with that revealed formerly by Mohamed (2009) who found that the infection rates were $80.95 \%, 80.64 \%, 80 \%$ and $75 \%$ during winter, autumn, summer and spring seasons, respectively in Sharkia Governorate and Abbassa fish farms.

\section{II- Crustacea:}

Concerning crustacean (Lamproglena monody) in O. niloticus, the present work clarified that the infection rate was 5.6\%; the low infection rate of crustacean infection in this study could be attributed to behavioral mechanisms such as avoiding or repelling the parasite by remaining in habitats that are not favorable to infective stages (Whitaker and Schlueter 1975). Moreover, this result was agreed for some extent with that found by Daniela (2009) and Mohamed (2009) who recorded the percent of infection was $4.2 \%$ and $7.82 \%$ respectively. However, the present study was higher than that recorded by Raef et al. (2000) who concluded that the prevalence was $2.45 \%$. On the contrary, the present investigation was lower as compared to that recorded by Eissa and Gharib (2005) and Ibraheem (2008) as they recorded that the overall prevalence were $15.83 \%$ and $22.86 \%$ respectively. The variation reason might be due to the changes in ecological factors, also due to differences in localities and water quality in these localities, and different of sample collection.

Dealing with their seasonal prevalence, the highest infection rate of Lamproglena monody was observed in winter (16.7\%) and the lowest rate was noticed in autumn $(5.6 \%)$, while the other seasons; summer and 
spring were free from infection. This might be attributed to the host lower resistance during this period of the year especially winter in which the stress of low water temperature reducing the fish immune response and disease resistance. Moreover, the present results were not in accordance with that found by El-Moghazy (2008) who mentioned that higher incidence recorded during summer (51\%) followed by spring $(48 \%)$, autumn $(36 \%)$ and winter $(30 \%)$. These differences in the rates and seasonal dynamics of infection between the different localities may be attributed to the differences in environmental conditions, fish species, and the differences in the degree of water pollution as well as number of examined samples.

\section{III- Protozoa:}

Regarding to the prevalence rate of Hennugya assuitti in C. lazera was $5.6 \%$. This result was nearly similar to that obtained by El-Bouhy et al. (2006) and Bassem (2011) where the infection rates were reached $6.1 \%$ and $4.11 \%$ respectively.

In regard to their seasonal dynamics, the present work showed that the peak of prevalence was observed during winter (16.7\%). This result was in contrary with that mentioned by El-Seify et al. (2011) who found that the highest infection rate was in spring $(66 \%)$. The seasonal data revealed that the outbreak of diseases found in the winter season for particular species leads to a conclusion that a biological factor of the host as well as the water quality may play an important role in that period. As the water quality parameters fluctuate very quickly during winter and summer season, fish becomes affected with diseases in these two seasons.

$\overline{\overline{\text { Kafrelsheikh Vet. Med. J. Vol. } 11 \text { No. } 2 \text { (2013) }}}$ 
A Survey On Ectoparasites Of Some Freshwater Fish At Qena ...

Table (1): Prevalence of different helminthes parasites among the examined fish at Qena Governorate

\begin{tabular}{|c|c|c|c|c|c|c|c|c|c|c|}
\hline \multirow{2}{*}{$\begin{array}{c}\text { Fish } \\
\text { species }\end{array}$} & \multirow{2}{*}{ Season } & \multirow{2}{*}{$\begin{array}{c}\text { No. of } \\
\text { Examined } \\
\text { fish }\end{array}$} & \multicolumn{2}{|c|}{$\begin{array}{c}\text { Total no of } \\
\text { infected fish }\end{array}$} & \multicolumn{2}{|c|}{ Monogenea } & \multicolumn{2}{|c|}{ Crustacea } & \multicolumn{2}{|c|}{ Protozoa } \\
\hline & & & No. & $\%$ & No. & $\%$ & No. & $\%$ & No. & $\%$ \\
\hline \multirow{4}{*}{$\begin{array}{c}\text { Tilapia } \\
\text { spp. }\end{array}$} & winter & 18 & 8 & 44.4 & 5 & 27.8 & 3 & 16.7 & 0 & 0 \\
\hline & spring & 18 & 2 & 11.1 & 2 & 11.1 & 0 & 0 & 0 & \\
\hline & summer & 18 & 0 & 0 & 0 & 0 & 0 & 0 & 0 & 0 \\
\hline & \begin{tabular}{|l|} 
autumn \\
\end{tabular} & 18 & 4 & 22.2 & 3 & 16.7 & 1 & 5.6 & 0 & 0 \\
\hline Total & & 72 & 14 & 19.4 & 10 & 13.9 & 4 & 5.6 & $\overline{\mathbf{0}}$ & $\overline{\mathbf{0}}$ \\
\hline \multirow{4}{*}{$\begin{array}{c}\text { Calarias } \\
\text { lazera }\end{array}$} & winter & 18 & 3 & 16.7 & 0 & 0 & 0 & 0 & 3 & 16.7 \\
\hline & spring & 18 & 2 & 11.1 & 2 & 11.1 & 0 & 0 & 0 & 0 \\
\hline & \begin{tabular}{|l|} 
summer \\
\end{tabular} & 18 & 2 & 11.1 & 1 & 5.6 & 0 & 0 & 1 & 5.6 \\
\hline & \begin{tabular}{|l|} 
autumn \\
\end{tabular} & 18 & 1 & 5.6 & 1 & 5.6 & 0 & 0 & 0 & 0 \\
\hline Total & & 72 & 8 & 11.1 & 4 & 5.6 & $\mathbf{0}$ & $\mathbf{0}$ & 4 & 5.6 \\
\hline \multirow{4}{*}{$\begin{array}{c}\text { Lates } \\
\text { niloticus }\end{array}$} & winter & 18 & 2 & 11.1 & 0 & 0 & 2 & 11.1 & 0 & 0 \\
\hline & spring & 18 & 1 & 5.6 & 0 & 0 & 1 & 5.6 & 0 & 0 \\
\hline & \begin{tabular}{|l|} 
summer \\
\end{tabular} & 18 & 0 & 0 & 0 & 0 & 0 & 0 & 0 & 0 \\
\hline & \begin{tabular}{|l|} 
autumn \\
\end{tabular} & 18 & 1 & 5.6 & 0 & 0 & 1 & 5.6 & 0 & 0 \\
\hline Total & & 72 & 4 & 5.6 & $\mathbf{0}$ & $\mathbf{0}$ & 4 & 5.6 & $\mathbf{0}$ & $\mathbf{0}$ \\
\hline \begin{tabular}{|l|} 
Overall \\
\end{tabular} & & 216 & 26 & 12.03 & 14 & 6.5 & 8 & 3.7 & 4 & 1.9 \\
\hline
\end{tabular}

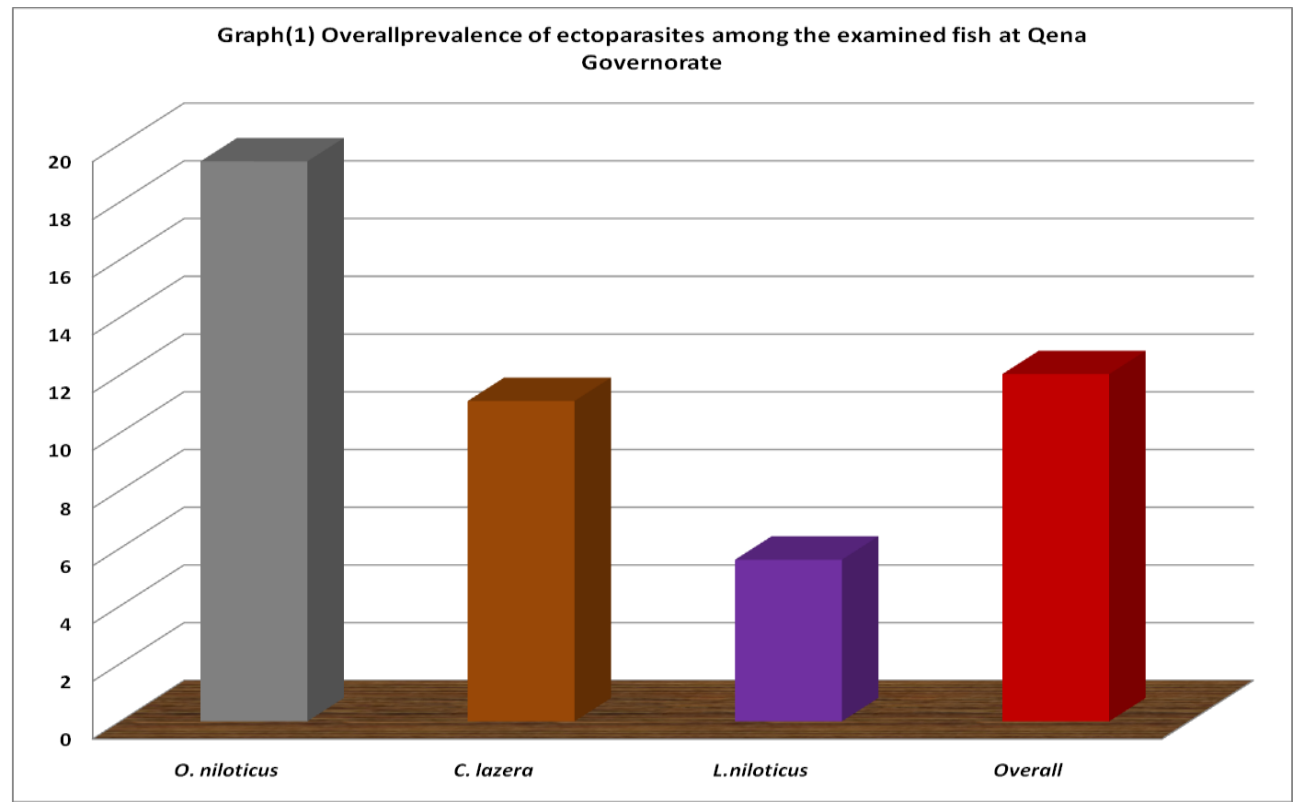

Kafrelsheikh Vet. Med. J. Vol. 11 No. 2 (2013) 
Mahmoud A. El-Seify et., al.
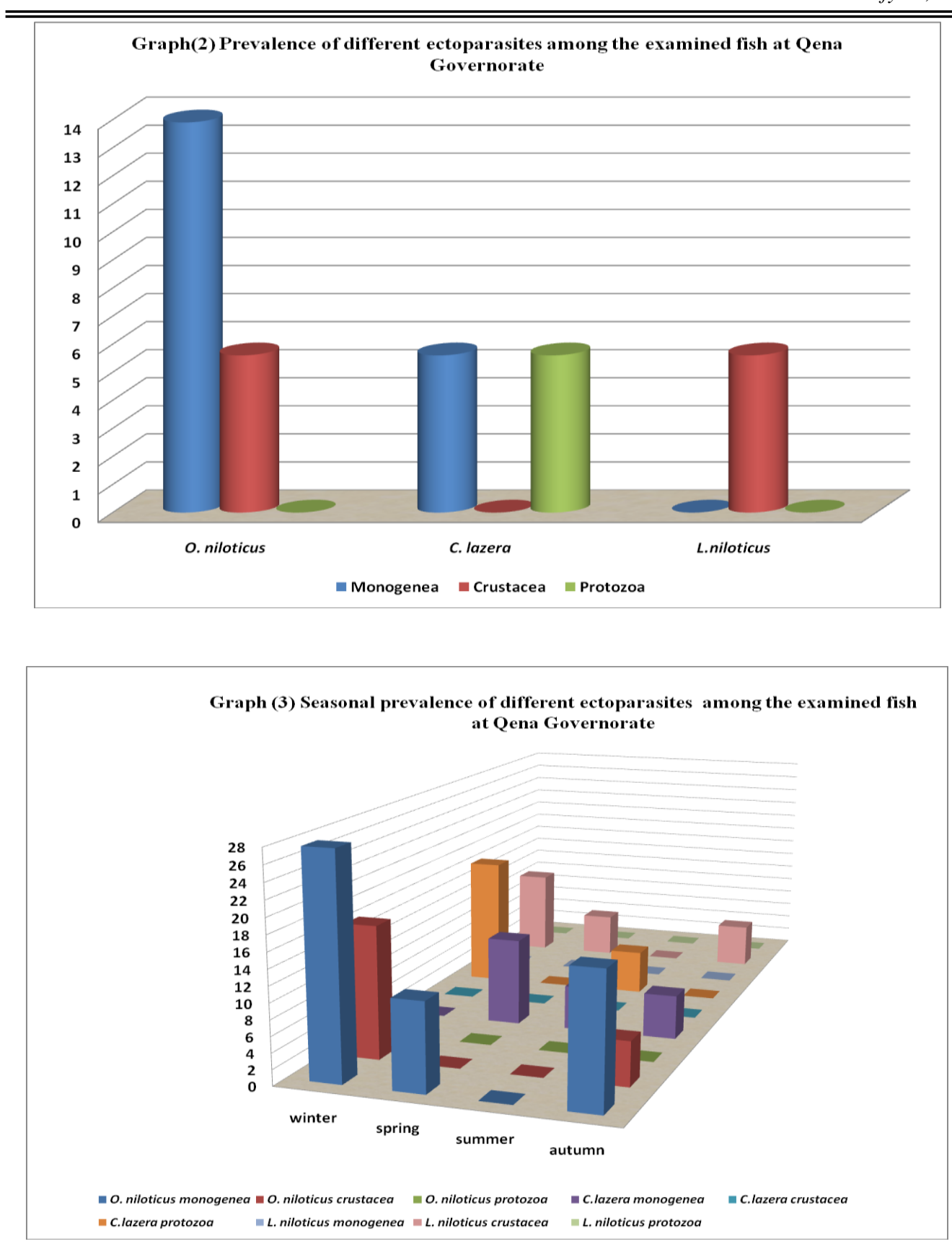

$\overline{\overline{\text { Kafrelsheikh Vet. Med. J. Vol. } 11 \text { No. } 2 \text { (2013) }}}$ 
A Survey On Ectoparasites Of Some Freshwater Fish At Qena ...

Table (2): Prevalence of different species of monogenetic trematodes among examined fish at Qena Governorate

\begin{tabular}{|c|c|c|c|c|c|}
\hline Helminth species & Parasite group & Fish species & No. of examined fish & No. of infected & $\%$ \\
\hline Cichlidogyrus arthracanthus & Trematodes & O. niloticus & 72 & 6 & 8.3 \\
\hline Euryhaliotrema lovejoyi & Trematodes & O. niloticus & 72 & 4 & 5.6 \\
\hline Dactylogyrus sp. & Trematodes & C. lazera & 72 & 3 & 4.2 \\
\hline
\end{tabular}

Graph (4) Prevalence of different species of monogenetic trematodes among examined fish at Qena Governorate

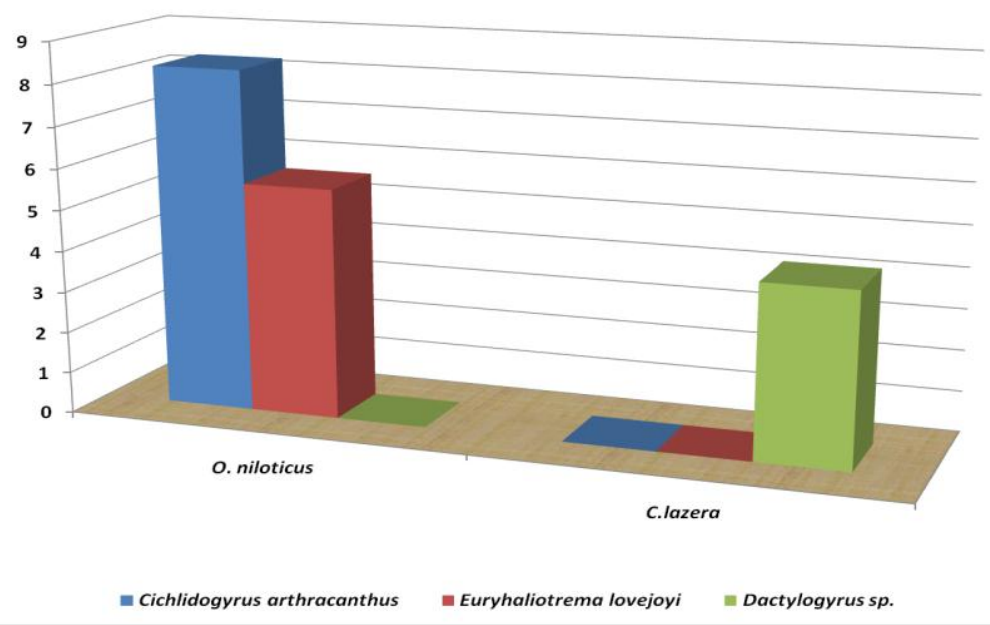

Table (3): Prevalence and intensity of different species of Protozoa and crustacea among examined fish at Qena Governorate

\begin{tabular}{|c|c|c|c|c|c|c|c|c|}
\hline \multirow{2}{*}{ Parasite species } & \multirow{2}{*}{$\begin{array}{c}\text { Parasite } \\
\text { group }\end{array}$} & \multirow{2}{*}{ Fish species } & \multirow{2}{*}{$\begin{array}{c}\text { No. of } \\
\text { examined fish }\end{array}$} & \multirow{2}{*}{$\begin{array}{c}\text { No. of } \\
\text { infected }\end{array}$} & \multirow{2}{*}{$\%$} & \multicolumn{3}{|c|}{ Intensity } \\
\hline & & & & & & Minimum & Maximum & Mean \\
\hline Henneguya assuiti & Protozoa & C. lazera & 72 & 3 & 4.2 & 1 & 7 & 4 \\
\hline Lamproglena monody & Crustacea & O. niloticus & 72 & 4 & 5.6 & 1 & 4 & 2 \\
\hline Ergasilus sarsi & Crustacea & L. niloticus & 72 & 3 & 4.2 & 3 & 5 & 4 \\
\hline
\end{tabular}

$\overline{\text { Kafrelsheikh Vet. Med. J. Vol. } 11 \text { No. } 2 \text { (2013) }}$ 
Graph (5) Prevalence of different species of Protozoa and crustacea among examined fish at $Q$ ena

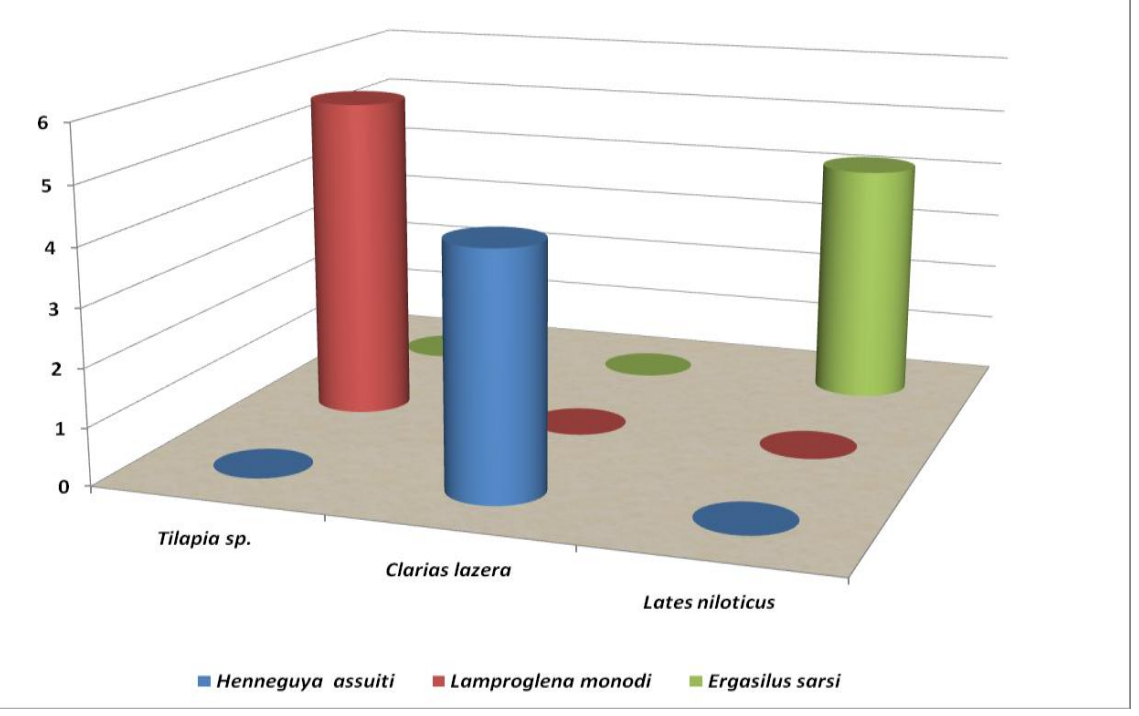

Table (4): Morphological description of the recovered monogenetic trematodes from the examined fish

\begin{tabular}{|c|c|c|c|}
\hline Parasites & Habitat & Common morphological features & Remarks \\
\hline $\begin{array}{c}\text { Cichlidogyrus } \\
\text { arthracanthus } \\
\text { (Paperna, 1960) }\end{array}$ & Gills of Tilapia sp. & $\begin{array}{l}\text { - One pair of pigmented eye spots } \\
\text { - Pharynx was subspherical and vitellariais } \\
\text { dense and occupying the most of entire body } \\
\text { of worm. } \\
\text { - The opisthaptor was dome-shaped provided by } \\
2 \text { pairs of anchors, } 6 \text { marginal hooklets and } 2 \\
\text { different connecting bars. }\end{array}$ & $\begin{array}{c}\text { Fig. } 1 \\
(a, b \& c)\end{array}$ \\
\hline $\begin{array}{c}\text { Euryhaliotrema } \\
\text { lovejoyi (Hargis, } \\
\text { 1955) }\end{array}$ & Gills of Tilapia sp. & $\begin{array}{l}\text { - Two pair of pigmented eye spots } \\
\text { - The opisthaptor has similar anchors, the dorsal } \\
\text { anchor bent around tip of the dorsal bar. } \\
\text { - Ventral bar is strait to broadly U-shaped }\end{array}$ & $\begin{array}{c}\text { Fig.1 } \\
\text { (d, e \& f) } \\
\text { Newly } \\
\text { recorded } \\
\text { species in } \\
\text { this study }\end{array}$ \\
\hline
\end{tabular}

$\overline{\text { Kafrelsheikh Vet. Med. J. Vol. } 11 \text { No. } 2 \text { (2013) }}$ 
Table (5): Morphological description of the recovered Protozoa and crustacea from the examined fish

\begin{tabular}{|c|c|c|c|}
\hline Parasites & Habitat & Common morphological features & Remarks \\
\hline $\begin{array}{c}\text { Henneguya assuiti } \\
\text { (Mandour et al., 1988) }\end{array}$ & $\begin{array}{l}\text { Gills and accessory } \\
\text { respiratory organs of } \\
\text { Clarias lazera }\end{array}$ & $\begin{array}{l}\text {-The cysts were ovoid to round, white creamy } \\
\text { in color, firm in consistency of variable sizes. } \\
\text { The ruptured cysts oozed viscid content } \\
\text { containing great number of henneguya } \\
\text { spores. } \\
\text { - Anteriorly there are } 2 \text { equal polar capsules } \\
\text { which being oval in shape. } \\
\text { - The sporoplasm was present posteriorly, } \\
\text { containing oval to rounded iodinophilous } \\
\text { vacuole; The posterior end of spore was } \\
\text { prolonged into one extended process. }\end{array}$ & $\begin{array}{l}\text { Fig.2 } \\
a, b, c \\
\& d\end{array}$ \\
\hline $\begin{array}{l}\text { Lamproglena monody } \\
\qquad \begin{array}{l}\text { (Female) } \\
\text { (Capart, 1944) }\end{array}\end{array}$ & $\begin{array}{c}\text { Gills of } \\
\text { Tillapia sp. }\end{array}$ & $\begin{array}{l}\text { - The head was as nearly wide as the middle } \\
\text { body region. } \\
\text { - Cephalothorax was more distinctly demarked } \\
\text { from each other, than the segmentation } \\
\text { regions. } \\
\text { - The abdomen consists of three segments, the } \\
\text { genital segment having two elongated } \\
\text { uniseriate egg sacs with flattened eggs } \\
\text { arranged in one row. }\end{array}$ & Fig. 2. e \\
\hline $\begin{array}{l}\text { Ergasilus sarsi } \\
\qquad \text { (Female) } \\
\text { (Capart, 1944) }\end{array}$ & $\begin{array}{c}\text { Gills of } \\
\text { Lates niloticus }\end{array}$ & $\begin{array}{l}\text { - The parasite was Cyclops like; the head and } \\
\text { the first thoracic segment were fused into } \\
\text { cephalothorax. } \\
\text { - The head had two pairs of segmented } \\
\text { antennae, of which the second antenna } \\
\text { terminal segment is hook-like. } \\
\text { - Abdomen was of three somites and the egg } \\
\text { sacs were elongated; filled with large number } \\
\text { of eggs. }\end{array}$ & Fig. 2.f \\
\hline
\end{tabular}

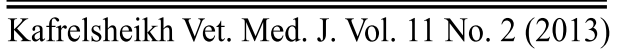



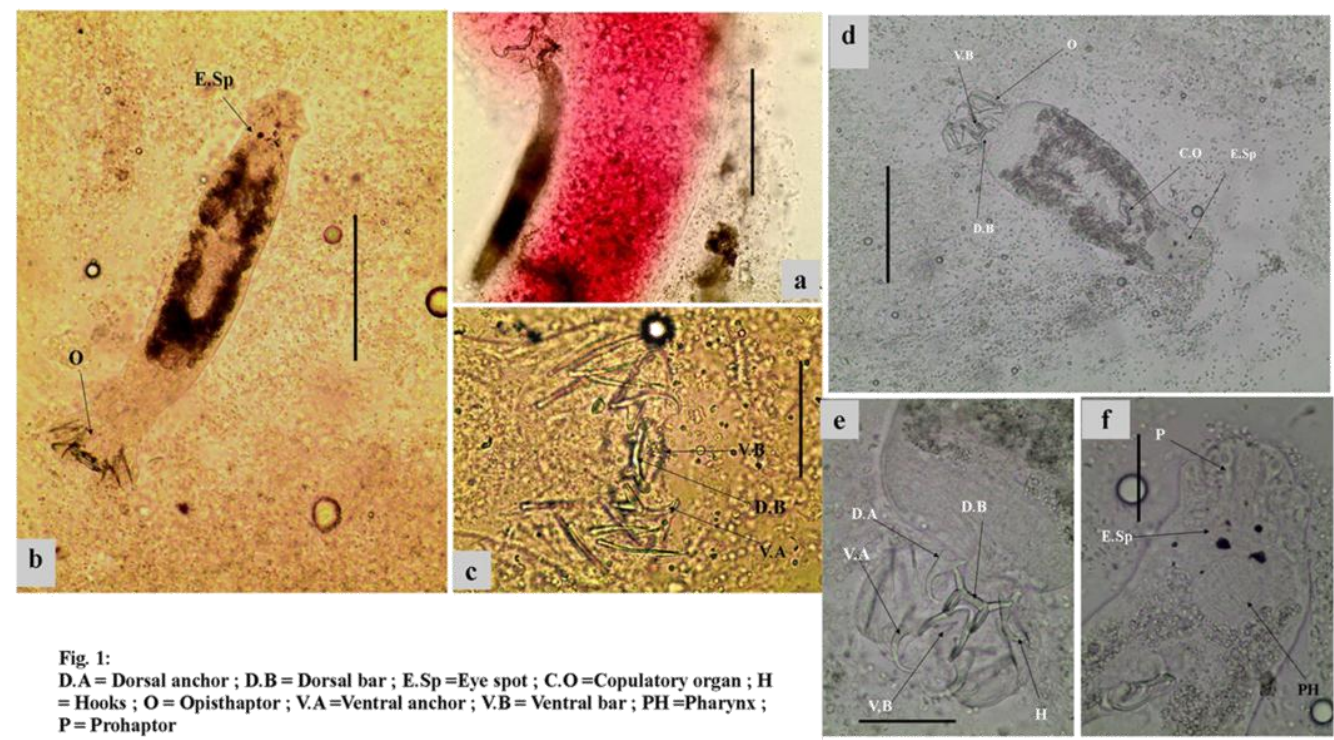

D. A = Dorsal anchor $; \mathbf{D} . \mathbf{B}=$ Dorsal bar $; \mathbf{E} . \mathbf{S p}=$ Eye spot $; \mathbf{C} . \mathbf{O}=$ Copulatory organ $; \mathbf{H}$

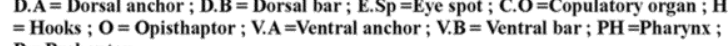

$\mathbf{P}=$ Prohaptor

Fig. (1):

a) Cichlidogyrus arthracanthus attached to gill filament

b) Cichlidogyrus arthracanthus

c) Cichlidogyrus arthracanthus (Opisthaptor)

d) Euryhaliotrema lovejoyi

e) Euryhaliotrema lovejoyif) (Opisthaptor)

f) Euryhaliotrema lovejoyi (Prohaptor)

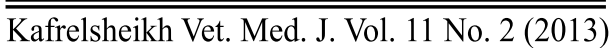



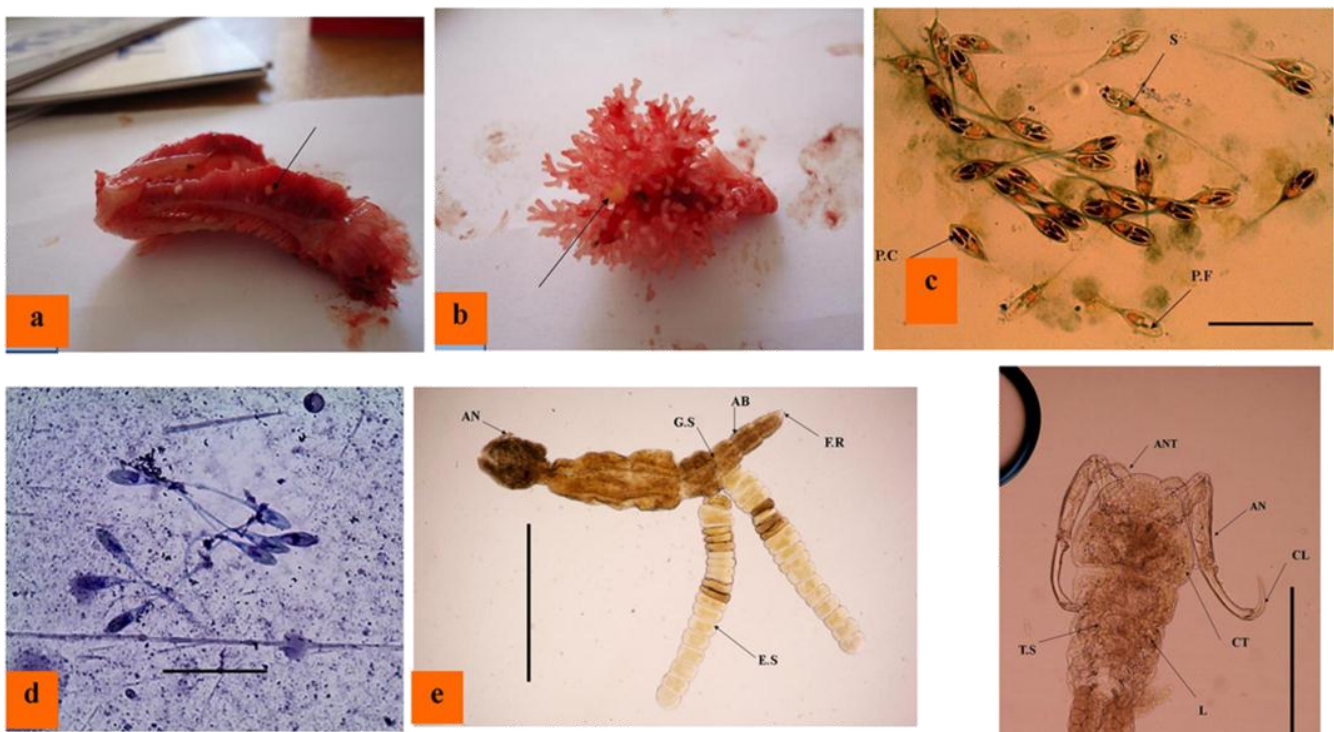

Fig. (2):

E.P =Extended process $; \mathbf{P . C}=$ Polar capsule; $\mathbf{P . F}=$ Polar filament; $\mathbf{S} . \mathbf{P}=$ Sporoplasm ; AB

$=$ Abdomen $; \mathbf{A n}=$ Antenna $;$ Ant $=$ Antennules $; \mathbf{C l}=$ Claw $; \mathbf{C T}=$ Cephalothorax $; \mathbf{E} . \mathbf{S}=\mathbf{E g g}$ sac $; \mathbf{F} . R=$ Furcal rami $;$ G.S $=$ Genital segment $; \mathbf{L}=\mathbf{L}$ egs; $T . S=$ Thoracic segment

Fig. (2):
a) Henneguya assuiti cyst in gill of Clarias lazera (Arrow)
b) Henneguya assuiti cyst in accessory respiratory organs of Clarias lazera (Arrow)
c) Henneguya assuiti (Lugol iodine stain)
d) Henneguya assuiti (Giemsa stain)
e) Lamproglena monody (Female)
f) Ergasilus sarsi (Female)

$\overline{\text { Kafrelsheikh Vet. Med. J. Vol. } 11 \text { No. } 2 \text { (2013) }}$ 


\section{REFERENCES}

- Abd El-Maged, R.R. (2009): Studies on ecto-parasites of freshwater fishes in Dakahlia Governorate. Ph.D. Thesis, Fac. Vet. Med., Kafrelsheikh Univ.

- Abo-Esa, J. F. K. (2008): Study on Some Ectoparasitic Diseases of Catfish, Clarias gariepinus with their Control by Ginger, Zingiber officiale. Mediterranean Aquaculture Journal, 1(1); 1-9.

- Adawy, R. S. M. (2000): Studies on parasitic diseases in some freshwater fishes in Dakahlia Governorate. Ph. D. Thesis. Fac.Vet. Med. Cairo Univ.

- Bassem, M.M. (2011): Studies on external parasites affecting fishes in Manzala Lake M. Sc. Thesis, in Parasitology, Fac. Vet. Med. Mansoura Univ.

- Blažek, R. , Polačik, M., Reichard, M. (2013): Rapid growth, early maturation and short generation time in African annual fishes. EvoDevo, 4: 24.

- Bonham, $\boldsymbol{k}$ and Guberlet, J. (1937): Notes on Mictocotyle sebastis Goto from Puget Sound. J. Parasit., 23:281-290.

- Daniela, F., Andrea, G., Monica C., Francesco T., Francesco Q., Robert K., Tanja, N. (2009): Veterinary and public health aspects in tilapia (Oreochromis niloticus niloticus) aquaculture in Kenya, Uganda and Ethiopia. Ittiopatologia, 2009, 6: 51-9351. 
A Survey On Ectoparasites Of Some Freshwater Fish At Qena ...

- Eissa, I.A.M. and Gharib, A.F. (2005): Studies on Lamproglenosis in cultured Oreochromis niloticus. Special. Egyptian Veterinary Medical Society of Parasitology Journal, 11 (2): 429-437.

- Eissa, I.A.M., Badran, A.F., Mahmoud, N.A. and Osman, H.A. (2002): Studies on henneguyosis in catfish, Clarias gariepinus. Suez Canal Vet. Medic. J., 1: 415-424

- El-Bouhy, Z. M.; Diab, A. S.; Sakr, S. F. and Abdel-Hadi, Y. M. (2006): Prevalence of some parasitic agents affecting the gills of some cultured fishes in Sharkia, Damietta and Fayium governorates. Zag. Vet. J., 34(2): 81-91.

- El-Moghazy, D.F. (2008): Studies on some parasitic diseases caused by harmful crastaceans in fish. Ph.D.Thesis, Fac. Vet.Med. Suez Canal University.

- El-Nobi, G. (1998): Studies on the main parasitic diseases affecting cultured fish and its influences by some ecological factors. Ph .D. Thesis, Fac. Vet. Med. Zag. Univ.

- El-Seify, M., Zaki, M., Desouky, A., Abbas, H., Abdel Hady, O. and Abou Zaid, A. (2011): Seasonal Variations and Prevalence of Some External Parasites Affecting Freshwater Fishes Reared at Upper Egypt. Life Science Journal, 2011; 8(3).

- Eman, I. M.M. (2008): Studies on some Internal Parasitic Diseases of Nile Tilapia in Kalubia Governorate. M. V. Sc. Thesis, Fac. Vet. Med., Benha . Univ. 
- Endrawes, M. N. (2001): Observations on some external and internal parasitic diseases in Nile catfish. M.V.Sc. Thesis, Fac. Vet. Med. Zagazig Univ.

- Gussev, $\boldsymbol{A V}$ (1985): Key to parasites of freshwater fishes of the USSR. In: Bauer ON, editor. Monogenea. Moscow: Nauka Publications. p. 87-99.

- Ibraheem, M. H. (2008): Lamproglena Monodi Capart, 1944, Attachment Scheme and Associated Pathology on the Gills of Oreochromis Niloticus Niloticus, with a Special Reference to Thoracic Appendages. Arab gulf journal of scientific research, 26 (3): 123-132.

- Lester, R.J.G. and Hayward, C.J. (2006): Protozoan and Metazoan Infections. 2nd ed. CAB international, London. Fish Diseases and Disorders, Vol. 1: , pp. 466-565.

- Lom, G. (1995): Trichodinidae and other ciliates (Phylum Ciliphora). Cited by Woo, P.T.K. (1995): Fish Diseases Disorders Protozoa, metazoan, infections CAP International.

- Minchella, D. J., and Scott, M. E. (1991): Parasitism: a cryptic determinant of animal community structure. Trends in Ecology \& Evolution 6,250-254.

- Mohamed E. A. A. (2009): Observation on the parasitic diseases infecting the blood and gills of some warm water fish. M. V. Sc. Thesis, Fac. Vet. Med., Zagazig Univ. 
- Osman, H. A. M. (2001): Studies on parasitic gill affections in some cultured freshwater fishes. M. V. Sc. Thesis. Fac. Vet. Med., Suez Canal University.

- Raef, A.M., El-Ashram, A.M. and El-Sayed, N.M. (2000): Crustacean parasites of some cultured freshwater fish and their control in Sharkia. Egypt. Vet. J., 28(2): 180-191.

- Ramadan, R. A. M. (2000): Morphological and immunological studies on certain ectoparasites of some freshwater fishes. Ph.D. Thesis, Fac. Vet. Med., Suez Canal Univ.

- Ravichandran, S., T. Balasubramanin and T. Kannupandi, (2007): Incidence of parasitic isopods on the fish Sphyraena obtusata. Res. J. Parasitol., 2(1): 45-50.

- Ravichandran, S., T.T. Ajithkumar, P.R. Ross and Muthulingam, M. (2010): Histopathology of the infestation of parasitic isopod Joryma tartoor of the host fish Parastromateus niger Res. J. Parasitol., 5(4): 303-306.

- Reed, C., Basson, L. and Van As, L.L. (2003): Myxozoans infecting the sharptooth catfish, Clarias gariepinus in the Okawango River and Delta, Botswana, including descriptions of two new species, Henneguya samochimensis sp. n. and Myxobolus gariepinus sp. n. Folia Parasitol., 50: 183-189. 
- Roche, D.G., Leung, B., Franco, E.F.M., Torchin, M.E. (2010): Higher parasite richness, abundance and impact in native versus introduced cichlid fishes. International Journal for Parasitology; 40 1525-1530.

- Saleh, G. A. and El-Nobi, G. A. (2003): Prevalence of Monogeniasis in Tilapia fish among different systems of fish management, seasons and fish life stages with special reference to the therapeutic effect of Praziquantel at different temperatures. Zag. Vet. J.; 31(1): 37-48.

- Whitaker, J.O. and Schlueter, R.A. (1975): Occurrence of the crustacean parasite, Lernaea cyprinacea, on fishes from the White River at Petersburg, Indiana. American Midland Naturalist 93: 446-450.

- Yamaguti, S. (1963): Systema helminthum, Vol. 4. Monogenea and Aspidocotylea .New York \& London: Interscience Publishers. P. 699. 